\section{REFERENCES}

1. Siddiqui JY, Fitz AE, Lawton RL, et al. Causes of death in patients receiving long-term hemodialysis. JAMA 1970;212:1350-1354.

2. Burton BT, Krueger KK Jr. National registry of long-term dialysis patients. JAMA 1971;218:718-722.

3. Lowrie EG, Lazarus JM, Mocelin AJ, et al. Survival of patients undergoing chronic hemodialysis and renal transplantation. N Engl J Med 1973;288:863-867.

4. Kirmani N, Tuazon CU, Murray HW, Parrish AE, Sheagren JN. Staphylococcus aureus carriage rate of patients receiving long-term hemodialysis. Arch Intern Med 1978;138:1657-1659.

5. Goldblum SE, Ulrich JA, Goldman RS, Reed WP. Nasal and cutaneous flora among hemodialysis patients and personnel: quantitative and qualitative characterization and patterns of staphylococcal carriage. Am J Kidney Dis 1982;2:281-286.

6. Uldall PR, Merchant N, Woods F, Yarworski U, Vas S. Changing subclavian hemodialysis cannulas to reduce infection. Lancet 1981;1:1373.

7. Sherertz RJ, Falk RJ, Huffman KA, Thomann CA, Mattern WD. Infections associated with subclavian Uldall catheters. Arch Intern Med 1983;143:52-56.

8. Kozeny GA, Venezio FR, Bansal VK, Vertuno LL, Hano JE. Incidence of subclavian dialysis catheter-related infections. Arch Intern Med 1984;144:1787-1789.

9. Cheesbrough JS, Finch RG, Burden RP. A prospective study of the mechanisms of infection associated with hemodialysis catheters. I Infect Dis 1986;154:579-588.

10. Dahlberg PJ, Yutuc WR, Newcomer KL. Subclavian hemodialysis catheter infections. Am J Kidney Dis 1986;7:421427.
11. Maki DG, Cobb L, Garman JK, et al. An attachable silverimpregnated cuff for prevention of infection with central venous catheters: a prospective randomized multicenter trial. Am J Med 1988;85:307-314.

12. Flowers RH, Schwenzer KJ, Kopel RF, et al. Efficacy of an attachable subcutaneous cuff for the prevention of intravascular catheter-related infection. A randomized, controlled trial. JAMA 1989;261:878-883.

13. Maki DG, Weise CE, Sarafin HW. A semiquantitative culture method for identifying intravenous catheter-related infections. N Engl J Med 1977;296:1305-1309.

14. SAS Institute. SAS/STAT User's Guide, Release. 6.03rd ed. Cary, NC: SAS Institute Inc; 1988.

15. Mehta CR, Patel NR, Gray R. Computing an exact confidence interval for the common odds ratio in several $2 \times 2$ contingency tables. J Am Statistical Assoc 1985;80:969-973.

16. Yu VL, Goetz A, Wagener M, et al. Staphylococcus aureus nasal carriage and infection in patients on hemodialysis, efficacy of antibiotic prophylaxis. N Engl J Med 1986;315:91-96.

17. Almirall J, Gonzalez J, Rello J, et al. Infection of hemodialysis catheters: incidence and mechanisms. Am J Nephrol 1989;9:454-459.

18. Cimochowski GE, Worley E, Rutherford WE, et al. Superiority of the internal jugular over the subclavian access for temporary dialysis. Nephron 1990;54:154-161.

19. Canaud B, Beraud JJ, Joyenx H, Mion C. Internal jugular vein cannulation using 2 Silastic catheters. A new, simple and safe long-term vascular access for extracorporeal treatment. Nephron 1986;43:133-136.

20. Kamal GD, Pfaller MA, Rempe LE, et al. Reduced intravascular catheter infection by antibiotic bonding. A prospective, randomized, controlled trial. JAMA 1991;265:2364-2368.

\title{
Senate Votes on Ryan White Act
}

\section{by Gina Pugliese, RN, MS Medical News Editor}

The Senate recently approved the reauthorization of the Ryan White CARE Act, a $\$ 633$ million program named after a young Indiana hemophiliac who acquired HIV from a blood transfusion. Jessie Helms (RepublicanNorth Carolina) lobbied against the reauthorization, criticized homosexuals, and called the AIDS prevention programs "thinly veiled attempts to restructure values of American families in favor of the homosexual lifestyle." Although Helms was defeated on the reauthorization issue, he did win some minor victories, including unanimous approval of a provision for optional attendance at federal workplace AIDS prevention programs. The Senate also approved a Helms proposal that prohibits the use of any Ryan White funds to promote homosexuality or intravenous drug use.

The Ryan White CARE Act expires at the end of September, unless it is reauthorized by Congress. The House will consider its version of the act in September, shortly before spending bills for the coming fiscal year are passed. Specific appropriations will be determined during the budget-making process, rather than in advance, as was the case in the current bill.

FROM: Helen D. Senate votes to continue AIDS program. Washington Post. July 28, 1995; p A 10. 